Canadian Journal of Higher Education Revue canadienne d'enseignement supérieur

Volume 45, No. 4, 2015, pages 18 - 41

\title{
Race, Gender, and Affirmative Action Attitudes in American and Canadian Universities
}

Ivan Katchanovski

University of Ottawa

Neil Nevitte

University of Toronto

Stanley Rothman

Smith College

\begin{abstract}
Direct comparisons of American and Canadian faculty and students' views concerning issues of race, gender, and affirmative action in higher education are rare. The 1999 North American Academic Study Survey provides a unique opportunity to analyze the role of national and positional factors in faculty and student attitudes towards race, gender, and affirmative action in the US and Canada. The findings indicate that national factors are more important than positional factors on many racial and affirmative-action issues. Differences between students and faculty are more pronounced than are cross-national variations on many gender-related issues.

\section{Résumé}

Rares sont les comparaisons directes entre l'opinion des corps professoral et étudiant des États-Unis et du Canada sur les problématiques liées à la nationalité, au sexe et à la discrimination positive dans l'enseignement supérieur. Le document 1999 North American Academic Study Survey donne l'occasion unique d'analyser le rôle des facteurs nationaux et socioculturels sur l'attitude des corps professoral et étudiant envers la nationalité, le sexe et la discrimination positive aux États-Unis et au Canada. Les résultats suggèrent que, pour plusieurs problématiques liées à la nationalité et à la discrimination positive, les facteurs nationaux sont plus importants que
\end{abstract}


les facteurs socioculturels. Pour plusieurs problématiques liées au sexe, on observe des différences d'attitudes plus marquées entre le corps professoral et le corps étudiant d'un même pays que d'un pays à l'autre.

\section{Introduction}

Race, gender and affirmative action remain among the most challenging issues facing American and Canadian higher education. The American and Canadian histories concerning race are quite different and each nation has adopted quite different approaches concerning the affirmative-action policies in higher education. Both countries, however, share strikingly similar histories when it comes to gender matters (Lipset, 1990).

This article explores the following questions: to what extent are there cross-national similarities and differences in faculty and student attitudes towards race, gender, and affirmative-action issues? To what extent, if at all, do minorities and women in higher education institutions on both sides of the border differ from their white and male counterparts? And, more generally, how similar or different are their evaluations of the academic climates for minorities and women? The focus is on faculty and student responses to matching surveys carried out in Canada and the United States. The historical experiences of both countries suggest that faculty and students in the US and Canada may well differ on racial issues and support for affirmative action. But when it comes to attitudes towards gender-related issues outlooks are more similar.

There is a long-standing record of survey-based Canadian-American comparisons across a variety of dimensions including social and political attitudes. (Adams, 2004; Lipset, 1990; Lipset, Meltz, Gomez, \& Katchanovski, 2004; Nevitte, 1996). While survey data show that Canadians are somewhat more tolerant towards outgroups (social groups that they do not identify with, such as racial minorities) than Americans, there are no surveybased comparative studies of race, gender, and affirmative action in higher education in the US and Canada.

This is the first study that draws directly on comparable survey evidence concerning faculty and student attitudes towards race, gender, and affirmative action in both countries. The evidence comes from the 1999 North American Academic Study Survey (NAASS), which is used to analyze attitudes towards racial, gender, and affirmative action issues among both faculty and undergraduate students in both Canada and the US. After reviewing previous research findings and contemporary policies in both countries, the analysis develops and tests a number of hypotheses. The concluding section summarizes the main findings of this study.

\section{The Canadian-American Comparison}

Canada provides a useful point of a comparison with the US because the economic, political, and value systems of these countries are strikingly similar. These similarities are also mirrored in important respects in the evaluation of their systems of higher education. Postsecondary educational opportunities in both countries expanded rapidly during the late 1960 s and early 1970s, and both countries have similar proportions of adult population with postsecondary education. By $2009,50 \%$ and $41 \%$ of the population aged 25 to 64 years old, respectively, in Canada and the US. held postsecondary qualifications. (OECD, 2011, pp. 41-42). 
Further research reveals another significant similarity in the academic cultures of the two countries: a substantial proportion of Canadian faculty received formal training at American universities and a significant number of Canadian faculty are American immigrants with American higher degrees. Although an overwhelming number (88\%) of faculty members in Canada are Canadian citizens, $40 \%$ of employed university teachers are immigrants and non-permanent residents. (CAUT, 2006, p. 19). According to data from NAASS, $12 \%$ of faculty members in Canada were born in the US, and $28 \%$ of faculty received their highest degree there.

However, beyond the similarities of the levels of postsecondary education among the populace and the American training frequently found in Canadian faculty, there are important differences in issues of race, gender, and affirmative action in higher education. These can be examined from a variety of theoretical perspectives, such as theories relating to critical race, culture, feminist studies, institutionalism, and rational choice. Such different theoretical approaches are often associated with either support for, or opposition to affirmative action (Bonilla-Silva, 2006; Feagin, Vera, \& Imani, 1996; Gmelch, 1998; Joshee \& Johnson, 2007; Kinder \& Sanders, 2006; Lipset, 1990; Rothman, Lipset, \& Nevitte, 2003; Taylor, Gillborn, \& Ladson-Billings, 2009).

Culture, defined in terms of economic, political, and social values, or as fundamental norms and orientations that often reflect historical legacies, is linked to American-Canadian national differences on a variety of issues. The cultural theories suggest that $\mathrm{Ca}-$ nadians have more social-democratic and collectivist values than Americans, who tend to hold relatively more individualist and laissez-faire values. Values change gradually. Previous studies indicate a trend toward a convergence of political values of Americans and Canadians, but a divergence of their social values. However, such values often also vary significantly within each country across different racial or ethnic groups (Abramson \& Inglehart, 1995; Adams, 2004; Alston, Morris, \& Vedlitz, 1996; Inglehart, Nevitte, \& Basanez, 1996; Lipset, 1990; Lipset et al., 2004; White, 2003).

The cultural or value-based theories were used to explain stronger support for unions in Canada (particularly among professors), compared to the US, where there is an absence of strong social-democratic parties (Katchanovski, Rothman, \& Nevitte, 2011; Lipset et al., 2004). Differences between the healthcare systems, as well as the foreign, economic, and social policies in Canada and the US, are also attributed to cultural or value-based theories (Adams, 2004; Alston, Morris, \& Vedlitz, 1996; Lipset, 1990). Culture theories also help to account for differences in the higher education systems and educational policies in the US and Canada (for example, the significant role of private universities in the US in contrast to Canada). While Canada does not have the formal affirmative-action policies that have been adopted in the US, employment equity in Canada has a significant similarity to affirmative action. The policies in both countries are similar in that they concern racial minorities and women, but they also differ in terms of their focus and other important features, such as the emphasis on specific groups, categories of employment, and the employers that they cover in the US and Canada (Agocs, 2002; Lipset, 1990).

Academic subcultures in different fields, institutional factors (such as program and institution type), and academic characteristics (such as tenure and academic achievement status), have also been shown to significantly relate to faculty and student attitudes toward racial, gender, and affirmative-action issues (Ladd \& Lipset, 1975). Previous survey- 
based research in the US and Canada show that different groups of professionals and professors in various academic fields, such as the social sciences, humanities, and natural sciences, differ in terms of their academic subcultures and political views (Ladd \& Lipset, 1975; Lipset et al., 2004; Nakhaie \& Brym, 1999).

The differences in historical legacies and experience concerning race and the composition of the population of racial minorities in the US and Canada are also likely to affect the attitudes of professors and students toward these issues. Issues surrounding slavery, for example, profoundly shaped American historical consciousness in unique ways. Canada served as a "terminal" at the end of the underground railroad, a network of routes to Canada used by some African American slaves seeking freedom. In contrast, the more prominent question of race confronting the Canadian population concerns the status of that country's indigenous people, in part because the Aboriginal people in Canada constitute a much greater proportion of the population than in the US. That said, the racial profiles of both the American and Canadian populations have become progressively more diverse and complex with the passage of time.

Historically, the American population and institutions of higher education have been more heterogeneous than their Canadian counterparts. But since the 1980s that gap has closed. Canada is one of the most immigrant-rich countries of all advanced industrial states, and the large influx of immigrants from nontraditional source countries over the last two decades has contributed significantly to the greater religious, ethnic, and racial diversity. Until about mid-nineties the Asian populations of both countries were historically quite small. With changing immigration patterns in the last two decades, however, Asians have become a more sizable significant minority on both sides of the border. The same demographic change also applies to the faculty and student populations.

\section{Changing Patterns}

Both the US and Canada have experienced greater racial diversity but the compositions of their respective minority populations, as well as students and faculty, differ. In the US, one fifth (21\%) of American undergraduate students in fall 2004 were Black, Asian, Pacific Islander, American Indian, or Alaska natives. In addition, 12\% of the American undergraduates were Hispanic, who are classified in the US as a separate group. Blacks (13\%) were the largest minority group among US students, followed by Asians (6\%). (Snyder, Tan, \& Hoffman, 2006). In Canada, the changing racial composition of many universities reflects the changes that have taken place more generally in Canadian society. By comparison to the US, visible minorities comprised $19 \%$ of Canadian undergraduates in the 2008 Canadian Undergraduate Survey Consortium Survey of Undergraduate University Students. The largest groups were Chinese (6\%), South Asian (3\%), Aboriginal (3\%), and Black (2\%) (Canadian University Consortium, 2008).

Racial minorities, including Hispanics, comprised about $16 \%$ of the full-time instructional faculty in American colleges and universities in fall 2003. That compares to about 11\% of Canadian faculty in 2001 (CAUT, 2006, p. 11; Snyder, Tan, \& Hoffman, 2006). According to NAASS, minority American faculty were made up of, 5\% Asian, 5\% Black, $1 \%$ Hispanic, and $3 \%$ other visible minorities. In contrast, the minority Canadian faculty were made up of $6 \%$ Asian, $1 \%$ African American, 2\% other, and $0.5 \%$ Hispanic; $1 \%$ did not specify their minority-group identity. 
The extent to which discrimination still hampers the access of racial minorities, especially African Americans, to higher education and academic careers in the US is a matter of some dispute. Overt discrimination and racism have almost certainly diminished, but researchers still claim that African Americans and Hispanics continue to be underrepresented among students at the most prestigious universities, and among faculty more generally. "Laissez-faire" racism, or "colour-blind" racism, may well qualify as a new form of racial prejudice among White students and academics. (Bonilla-Silva, 2006; Feagin et al., 1996).

The issues surrounding race may also apply to Asian professors and students, notwithstanding the overrepresentation of Asian Americans, "a model minority," at elite schools (Egan, 2007). Moreover, some evidence indicates significant differences in how different racial groups evaluate their university experience. For example, Black students are much more likely than their White counterparts to report racial conflict on campus and worse treatment by faculty. (Ancis, Sedlacek, \& Mohr, 2000; Ladd \& Lipset, 1975).

\section{Challenges}

When it comes to matters of race, Canadian universities may now be facing the same kinds of issues that have challenged American colleges and universities for decades. These issues are less contentious, certainly, and they resonate somewhat differently in the Canadian setting. Data indicate that racism, discrimination against minority students and faculty, levels of alienation of these groups, and the neglect of racial issues in the curriculum are commonplace in Canadian universities (Chan, 2005; Henry \& Tator, 1994). Samuel and Burney (2003), for example, claim that South Asian students experience both overt and covert racism in Canadian university settings. And minority faculty members report a higher incidence of mistreatment by university administrators than do their White counterparts (Nakhaie, 2004). The Canadian research record on these issues, however, is modest and the results somewhat mixed. Some counter that racism, discrimination, and unfair treatment of minority faculty and students in Canada are not very prevalent. (Bercuson, Bothwell, \& Granatstein, 1997; Grayson, 1995).

\section{Women in Higher Education}

One of the most striking characteristics associated with the expansion and structural changes to higher education systems in both the US and Canada has been the massive influx of women into postsecondary education. By 2003, women comprised $56 \%$ of American undergraduate students and 58\% of Canadian undergraduates in the 2003-2004 academic year (CAUT, 2006, p. 21; U.S, Department of Education, 2006). Those majorities do not yet apply to the professoriate. Female professors represented $36 \%$ of the full-time faculty in 4-year American institutions in 2003, compared to 32\% of university teachers in Canada in 2003-2004 (CAUT, 2006, p. 15; U.S. Department of Education, 2004).

Both American and Canadian universities have become sensitized to gender issues. Numerous investigations have been concerned with the treatment of female professors in the US and, to a lesser extent, in Canada, and treatment of female students in Canada and the US. Nonetheless, the change has been gradual and women remain underrepresented among faculty, particularly among tenured faculty, full professors, and university chairs, 
and in elite schools and in fields such as science and engineering. (Bercuson et al., 1997; Goyder, 1992, Rothman, Lichter, \& Nevitte, 2005; U.S. Department of Education, 2004.) Even though the extent to which higher education institutions in Canada and the US are sexist, biased in terms of curriculum and uncaring about the needs and interests of female students and professors, these issues are a matter of vigorous debate, and the data addressing these questions are mostly qualitative. (Chan, 2005; Gmelch, 1998).

Whether the patterns of the underrepresentation of women constitute prima facie proof of gender-based discrimination remains an unsettled question. Some interpret the relative lack of female full professors as evidence that women in the US and Canada face "a glass ceiling" (Bain \& Cummings, 2000; Toutkoushian \& Conley, 2005). Others contend that the underrepresentation of women in the American and Canadian academy is attributable to self-selection, particularly among upper ranks of faculty, at top universities, and in some fields and disciplines. This self-selection, some claim, reflects the choices made by women who strive to strike an optimal balance between her academic career and family, and to prior socialization (Nakhaie, 2002).

In the US, affirmative-action policies have been directed at dealing with issues of underrepresentation of racial minorities and women, and related issues in colleges and universities. Such federal laws as the Equal Pay Act and the Civil Rights Act, championed in the 1960s, aimed to overcome gender and racial discrimination and to promote greater equality. Title IX of the Educational Amendments of 1972 banned sex discrimination in educational programs, and directions from the Department of Health, Education, and Welfare prohibited discrimination against women in university admissions and faculty hiring. (Anderson, 2004, pp. 142-144).

The U.S. Supreme Court has played a decisive role in the adoption of these policies. In University of Caifornia v. Bakke (1978), Justice Powell's separate opinion broached the view that diversity is a constitutionally justifiable principle for affirmative action programs. The diversity principle was adopted by a majority of the justices in Grutter $v$. Bollinger (2003) as well as Gratz $v$. Bollinger (2003) and later affirmed, albeit less resolutely, by a majority in Fisher $v$. University of Texas (2013).

Some survey evidence from the American academy indicates that students and faculty want to increase the diversity of the student body and the faculty (Levine \& Cureton, 1998). But levels of support specifically for affirmative-action programs seem to vary depending on how survey questions are worded. Thus, other research finds that majorities of American faculty and students are opposed to special preferences in student admissions and faculty hiring (Rothman et al., 2003).

Canadian courts have been less heavily engaged in affirmative-action-type matters than their U.S. counterparts. As in many European countries, but unlike the US, Canada has a constitutional precommitment to race and gender-based employment equity. The Canadian Charter of Rights and Freedoms, incorporated into the Canadian Constitution in 1982, does not explicitly stipulate affirmative action for higher education or other areas. Rather, it treats group preferences as legally compatible with equal protection. Thus, unlike in the US, the Supreme Court of Canada and lower courts have constitutional authority to protect the legal basis of affirmative action. The Supreme Court of Canada, however, can limit the scope of affirmative action in higher education in its interpretation of the law (Brooks, 2005). 
The US might be viewed as having a "hard" affirmative-action approach, while Canada has adopted what might be called a "soft" affirmative-action approach. Canadian universities do take race and gender into account in their hiring and admission decisions. According to a Canadian Federation of Women Survey, for example, half of Canadian universities had affirmative-action strategies to increase the number of hired and promoted female faculty members (Saunders, Therrien, \& Williams, 1992, p. 57). A review of employment equity plans on university websites in Canada indicates that the proportion of universities with such programs is now much higher. Employment announcements concerning faculty searches routinely include statements expressing the commitment of Canadian universities to diversity and welcoming applications from visible minority-group members, Aboriginal persons, and women. Indeed, collective agreements at some universities contain provisions that give preference to qualified racial minorities and women when it comes to tenure-stream faculty positions.

The surrounding legislative context in Canada is also somewhat different from the U.S. legal environment. The Canadian Multiculturalism Act (1988), preceded or followed by similar provincial legislation, provides a legal foundation for multicultural policies in a variety of domains, including higher education. The Employment Equity Act (1986), which applies to Canadian universities, is designed to eliminate discrimination and barriers in the hiring of visible minorities, Aboriginal people, and women (Chan, 2005). Whether these legal standards, or contextual matters, are reflected in variations within and between academic institutions on both sides of the border is less clear.

Previous studies based on nationwide surveys generally focused on analysis of public attitudes towards affirmative action in the US (Kinder \& Sanders, 1996). National surveybased studies drawing on large random samples of both faculty and students are rare in the US, and rarer still in Canada. A number of surveys conducted by the Carnegie Foundation in the US (since its monumental 1969 survey of faculty and students) provide valuable data concerning the treatment of minority and female faculty in such areas as tenure and academic scholarship (Boyer, 1990; Ladd \& Lipset, 1975). Periodic large-scale surveys of faculty and freshmen have also been conducted, although these samples were not random (Astin, Korn, \& Dey, 1991).

\section{Data and Hypotheses}

NAASS comes from a matched telephone survey administered in the US and Canada in 1999-2000 by Angus Reid survey organization. The survey contains a structured random sample of 1,644 faculty members and 1,632 undergraduate students in the US, and comparable samples of 1,514 faculty members and 1,509 students in Canada. ${ }^{1}$ Weighted American and Canadian samples of faculty and students closely match the respective populations in terms of major characteristics, such as university type, gender, race, and age.

One of limitations of this study is that it based on a survey conducted in 1999-2000. Therefore, this study does not claim to reflect the present-day attitudes of faculty and students toward race, gender, and affirmative action in the US and Canada because views of these issues could have changed since the time when NAASS was conducted. However, these attitudes were unlikely to undergo a radical transformation since that time. The evidence is that these kinds of change tend to take place gradually (Abramson \& Inglehart, 1995). 
Even though NAASS was conducted in 1999-2000, it remains one of the relatively newest and most comprehensive comparative national surveys of attitudes of faculty and students towards race, gender, and affirmative action in the US and Canada. Similar surveys are confined to either Canada or the US, include one of these categories of the respondents, or are based on a non-representative sample of selected universities. The strength of NAASS is that it represents a unique and directly comparable data source for addressing the views of American and Canadian professors and students regarding important gender and race issues and affirmative-action policies in higher education.

The first hypothesis examines whether cross-national factors are more important determinants of attitudes on racial and affirmative action issues than positional factors. Cross-national factors refer to differences between the US and Canada. Positional factors refer to the different positions that faculty and students occupy within those same higher education institutions. The second hypothesis is that positional factors are more important determinants of attitudes on gender issues than cross-national factors. We also hypothesize that there will be significant differences by race and gender among faculty and students alike in both countries.

The analysis begins by examining national and positional differences among White and non-White faculty and students, and male and female faculty and students. Because postsecondary education institutions in Canada are almost exclusively public, the first part of the analysis compares American public universities with their Canadian counterparts. ${ }^{2}$

NAASS contained questionnaire items tapping various dimensions of racial outlooks: racial discrimination, the treatment of racial minorities, attitudes towards courses on the experience of racial minorities, and the role of race in faculty hiring. The survey also included a variety of questions concerning gender issues. Specifically, it probed orientation towards sexual harassment, fair treatment of minorities and women, perceptions of unfair treatment because of race, ethnicity, gender, sexual orientation, religious beliefs, or political views, groups disadvantaged in the hiring process, and other related opinions. Measures of attitudes towards affirmative action are drawn from another set of questions dealing with race and gender-based preferences in faculty hiring or admissions of students. (See Appendix A for wording and coding of the questions. ${ }^{3}$ )

The analysis begins with a presentation of the basic data; it then turns to multivariate strategies to explore whether the same or different factors predict attitudes towards racial, gender, and affirmative-action issues in Canada and the US. The broad focus includes faculty and students from all schools in the Canadian and U.S. samples. Respondents from both public and private universities and colleges in the US are included in this part of the analysis. ${ }^{4}$ Differences between specific racial groups are also examined. ${ }^{5}$ Dependent variables are derived from the questions concerning various aspects of race and gender-related issues and attitudes towards affirmative action. Key dependent variables include measures of societal racism, racial discrimination, minority-student treatment, unfair treatment, courses on racial minorities, traditional standards of merit, special hiring policies, sexual harassment, treatment of female students, courses on women, and the affirmative-action index (see online Appendix A).

The affirmative-action index measures support for, and opposition to affirmative action. Results of a factor analysis of responses to questions relating to affirmative action in NAASS suggest that the three questions that directly tap respondents' views about affir- 
mative action form one factor. The index comes from responses to the following questions in NAASS (See online Appendix A):

1. More minority group undergraduates should be admitted here even if it means relaxing normal academic standards of admission.

2. The normal academic requirements should be relaxed in appointing members of minority groups to the faculty here.

3. No one should be given special preference in jobs or college admissions on the basis of their gender or race. (see online Appendix A).

The reliability coefficient for the index is reasonably robust (alpha $=0.67$ ).

The independent variables include a variety of socio-economic, institutional, and academic factors. ${ }^{6}$ The primary socio-economic factors include measures of race, gender, sexual orientation, past or current immigration status, household income, religiosity, and faculty age. Institutional variables include program type and institution type. The institution type (the public university dummy variable) is limited to the analysis of the U.S. sample. Academic factors include academic field of study, the academic achievement index, and tenure status (see online Appendix B). ${ }^{7}$ These variables are selected for a combination of theoretical and empirical reasons. ${ }^{8}$ Previous research, mostly focused on the US, has identified such socio-economic characteristics as race, gender, sexual orientation, income, religiosity, and age as important predictors of key orientations. Institutional factors, such as program type and institution type, and academic characteristics, such as field of study, tenure status, category of professionals, and academic achievement status, have also been repeatedly shown to be significantly related to faculty and student attitudes towards racial, gender, and affirmative action issues ${ }^{9}$ (Ladd \& Lipset, 1975).

\section{Basic Results}

\section{Race}

When it comes to general perceptions about the scope and scale of racism in American and Canadian societies, national differences turn out to be more important than positional or racial variations across faculty and students. The national differences concerning racial issues are statistically significant in all cases, with the sole exception of reported unfair treatment by White faculty. American faculty members (73\% non-White; 60\% White) are far more likely than their Canadian counterparts (31\% non-White; $32 \%$ White) to agree or strongly agree with the statement that America or Canada, in particular, Quebec, is a racist society. The same basic pattern of responses is also found among American and Canadian students. American students (65\% non-White; 64\% White), are more than twice as likely as their Canadian counterparts (28\% non-White; $26 \%$ White) to evaluate their society as a racist one. The national differences on this issue for White and non-White faculty and students are statistically significant at the $0.1 \%$ level. Canadian faculty and students reach essentially the same judgment on that question; in this particular case, the respondent's race matters little since the differences are statistically insignificant. In the case of American faculty members, unlike their student co-nationals, non-White faculty members are significantly more likely than their White counterparts to view America as a racist society. This relationship is also statistically significant (see Table 1). 


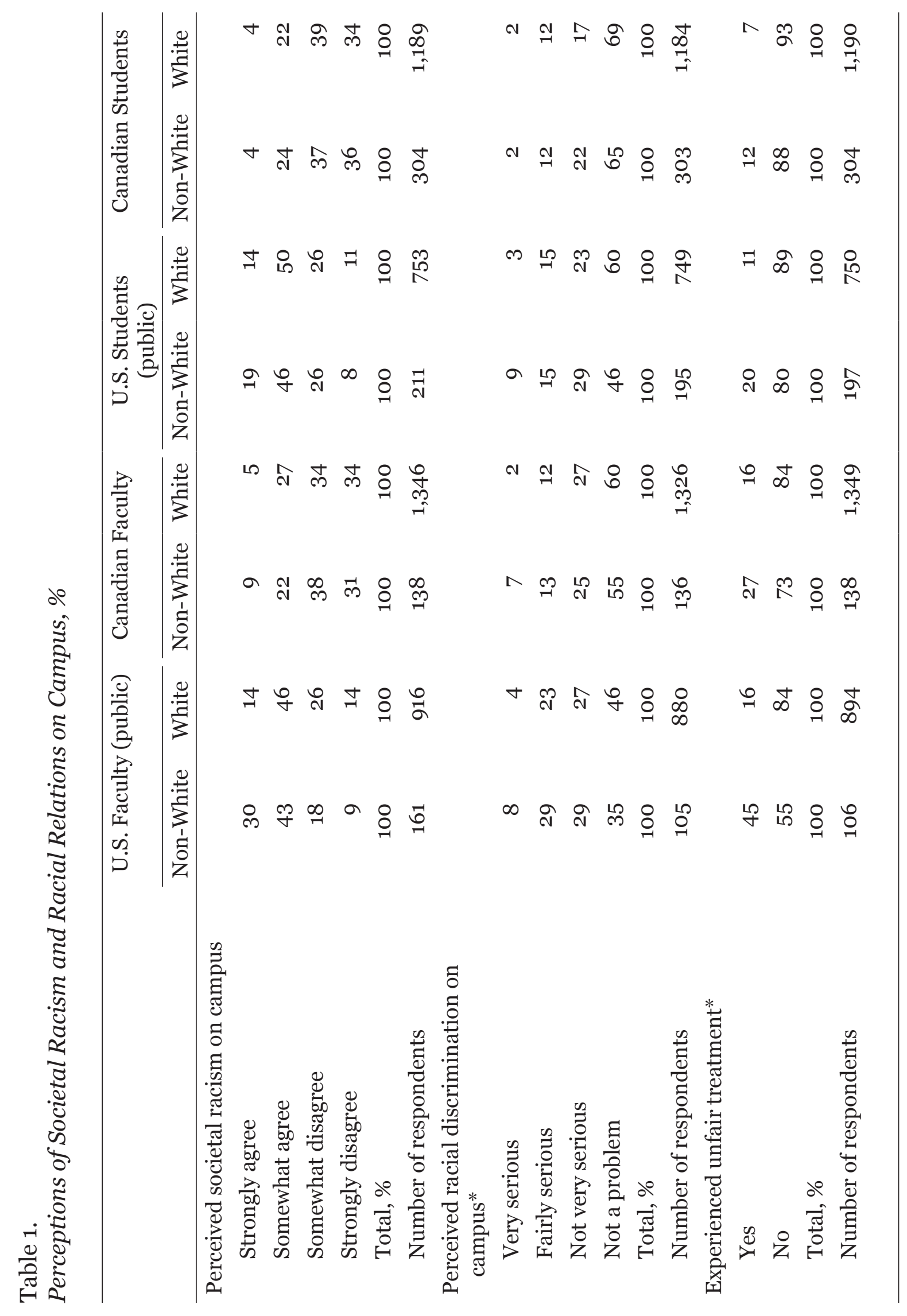


Race, Gender, \& Affirmative Action / I. Katchanovski, N. Nevitte, \& S. Rothman 28

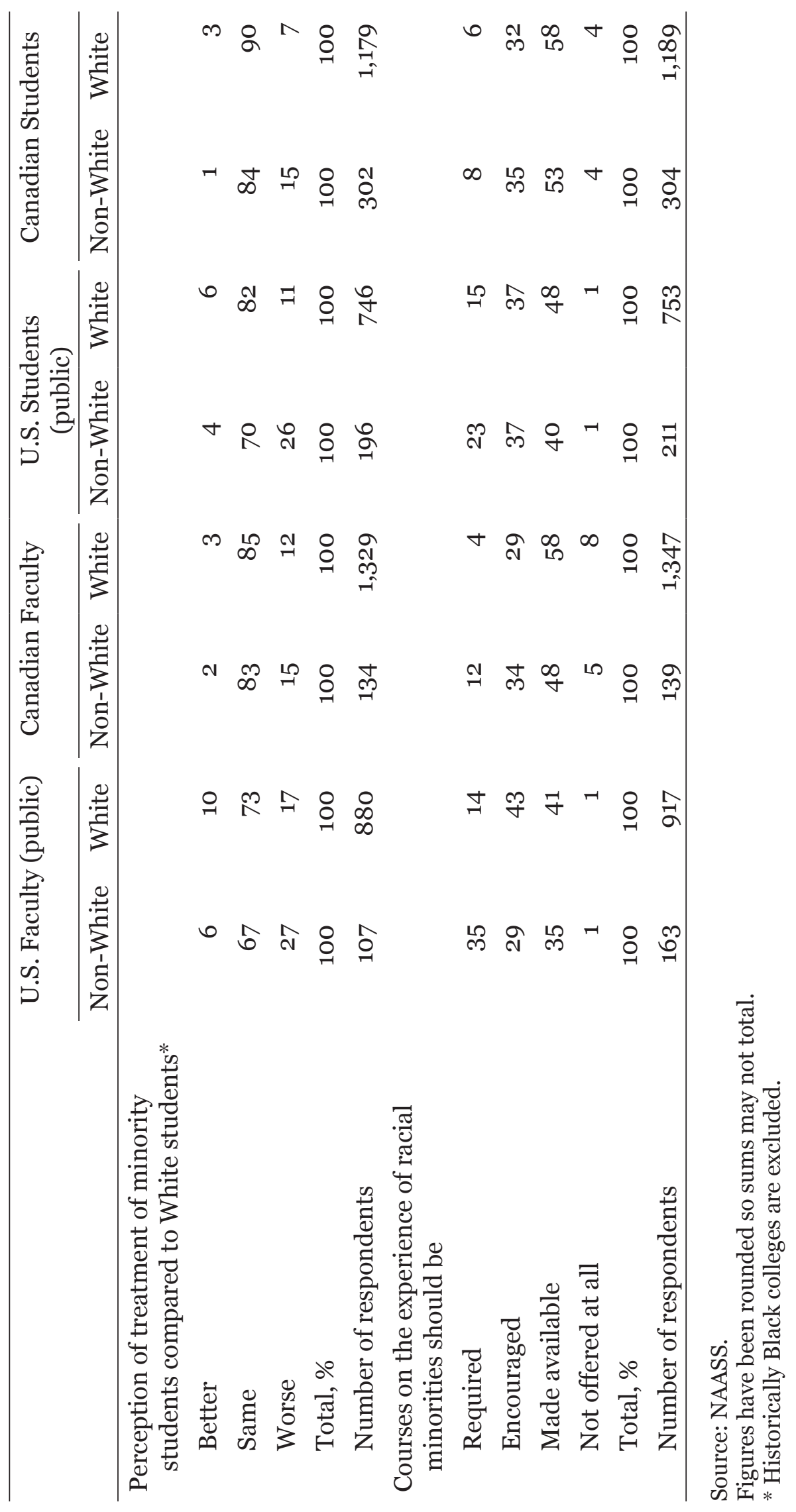


There is no reason to suppose that respondents will simply transfer their general evaluations of society to their particular campus setting. And on balance, the data indicate that they do not. All respondents in NAASS were asked whether they thought racial discrimination was "very" or "fairly" serious problem, "not [a] serious" problem, or "not a problem at all" on campus. American respondents were still significantly more likely than their Canadian counterparts to identify racial discrimination as a "very" or "fairly" serious problem (see online Appendix A). And non-White U.S. faculty (37\%) were more inclined than either non-White students (24\%, US; $14 \%$, Canada) or non-White Canadian faculty (20\%) to reach that judgment. The national differences on this issue are statistically significant at $0.1 \%$ or $1 \%$ levels. The race of student respondents, or of Canadian faculty respondents, does not matter much to these evaluations; the racial differences are not statistically significant. On balance, the national patterns are strikingly consistent. A majority of each group of U.S. respondents, with the exception of White students, believe that racial discrimination was at least to some degree a problem. Most Canadian respondents, regardless of their race, think that racial discrimination is "not a problem."

When it comes to perceptions about minority students treatment compared to White students, a clear majority of all respondent groups reported that they were treated "the same." But, there is a greater consensus among Canadian respondents on that matter. American non-White respondents are significantly more likely than their Canadian counterparts to take the view that minorities are treated worse. That finding holds regardless of whether respondents were faculty members or students, and the results are statistically significant at $0.1 \%$ or $1 \%$ levels.

Evaluations of whether respondents have experienced unfair treatment because of race, ethnicity, gender, sexual orientation, religious beliefs, or political views engage a much broader set of considerations. And in this instance, it is the positional differences, the differences between faculty and students that are statistically significant. Moreover, these positional differences seem to outweigh national variations.

Non-White professors in American public universities (45\%) are more than twice as likely as their student counterparts (20\%) to report that they had experienced unfair treatment. And the ratio is about the same for Canadian respondents: faculty members (27\% non-White, $16 \%$ White) are about twice as likely as their student counterparts (12\% nonWhite, 7\% White) to report that they had experienced unfair treatment on these broader grounds. These positional differences, arguably, might be attributable to variations in exposure. Faculty members certainly have a more sustained exposure to campus life than students and so it is possible that these positional variations reflect greater opportunities to experience unfair treatment (see Table 1).

If views about the unfair treatment of groups are attributable to the lack of understanding of the experience of racial minorities, then one possible remedy is to promote a greater understanding by educating people about the experiences of racial minorities. All respondents were asked if formal courses with such a goal should be "required," "encouraged," "made available," or "not offered at all." Once again, the pattern of responses reveals greater national than positional variations. American faculty and students, White or non-White, are more inclined than their Canadian counterparts to think that these courses should be "required." The differences are statistically significant at the $0.1 \%$ level. Non-White American respondents are also consistently more inclined than their Cana- 
dian counterparts to believe that the treatment of minority students is "worse" than that of White students. Non-White faculty and students at public colleges and universities in the US are more likely than both their White and Canadian counterparts to agree with the view that "traditional standards of merit for jobs and school admissions are basically affirmative action for White males." (Table 1 ).

White faculty and students are more inclined than non-White faculty and students in both countries, to hold the view that special hiring policies for minority faculty lower academic standards. Similarly, NAASS data reveal significant differences between nonWhite and White professors in their assessments about which groups face the toughest time getting hired for a faculty position at the average U.S. or Canadian university. These differences are statistically significant at the $0.1 \%$ level in both countries.

The pool of respondents in some racial minority groups turns out to be too small to warrant reliable conclusions about Asian and African American attitudes. Consequently, we turn to regression analysis to test the hypothesis concerning the different patterns of attitudes of Asian and Black respondents towards racial and affirmative action issues.

\section{Gender}

Positional differences between faculty members and students outweigh AmericanCanadian differences when it comes to perceptions about such issues as sexual harassment on campus, the treatment of female students, and personal experience of unfair treatment. In both Canada and the US, professors, particularly female professors, are significantly more likely than students to regard sexual harassment as a problem. They are also more likely to report experience of unfair treatment and to believe that female students are treated worse than their male counterparts. The differences are statistically significant. The only exception to that pattern comes from male respondents on the question concerning experience of unfair treatment (see Table 2).

About one third of female faculty in American (32\%) and Canadian (33\%) public universities, compared to one in five American (21\%) and Canadian (20\%) female students, regard sexual harassment as a serious problem on their campuses. Similarly, 18\% of women faculty in Canada (and 19\% of their American counterparts), compared to 6\% of Canadian students and 4\% of American undergraduates in public universities, believe that female students in their institutions of higher education are treated worse than male students. Just $3 \%$ of both male faculty and students in Canada, and only $4 \%$ of male public university students, and $5 \%$ of male faculty in the US hold that view. American faculty and students are more inclined than their Canadian counterparts to support the teaching of courses about the experience of women. But students in both countries are less inclined than faculty to support that idea. (See Table 2).

Significant gender differences emerge in both countries when it comes to judgments about which groups have the most difficulty getting faculty positions. Among American female professors, $46 \%$, think that minority or White females face the biggest disadvantage; $25 \%$ of their male colleagues share this view. Among Canadian faculty 50\% of women and $31 \%$ of men express that view. The relationship is statistically significant at the $0.1 \%$ level in both cases. These national and positional differences might be considered minor, but they are systematic and a similar gender gap is evident when it comes to perceptions about whether traditional standards of merit operate as affirmative action for white males. 
Race, Gender, \& Affirmative Action / I. Katchanovski, N. Nevitte, \& S. Rothman 31

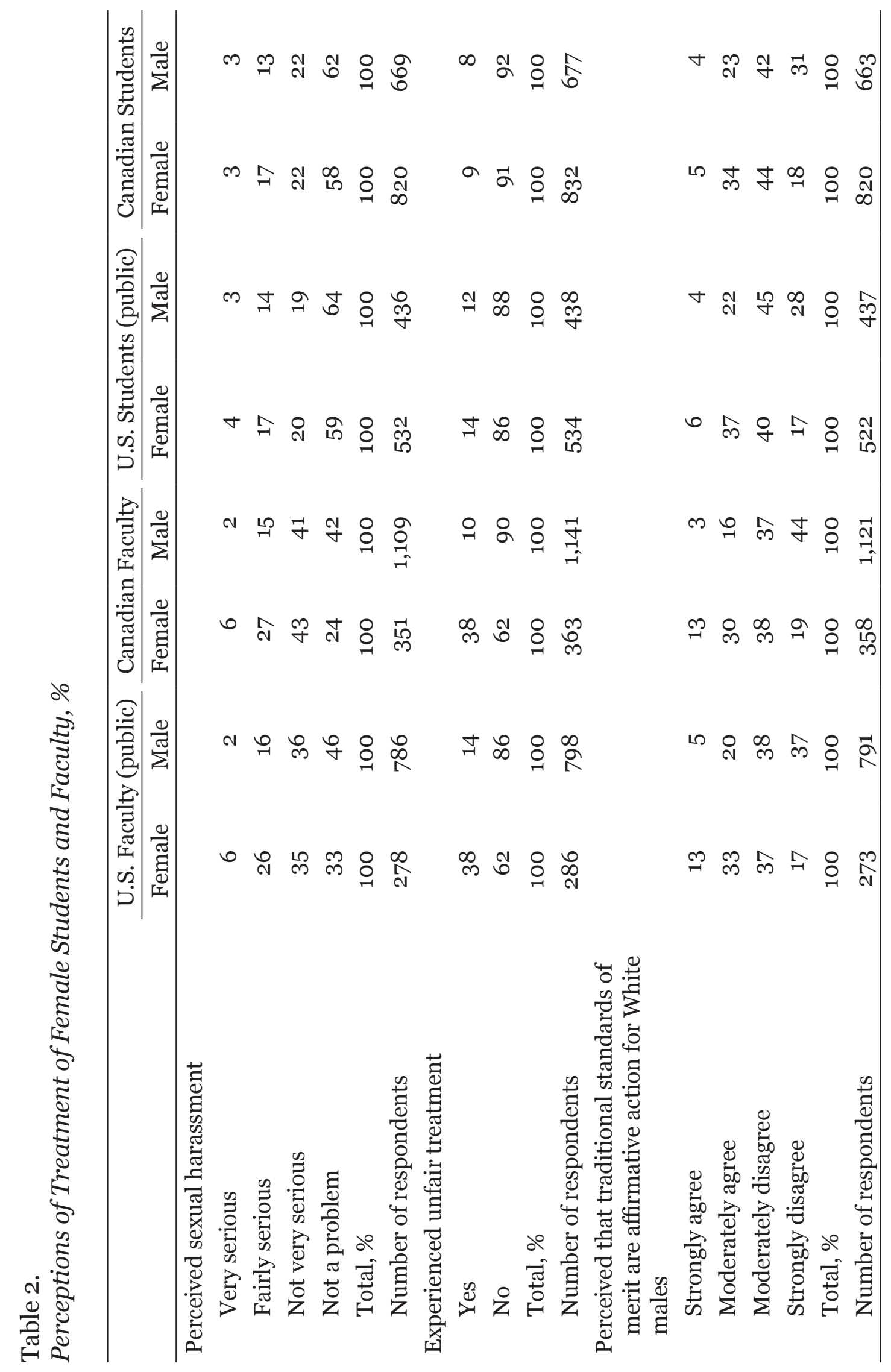


Race, Gender, \& Affirmative Action / I. Katchanovski, N. Nevitte, \& S. Rothman 32

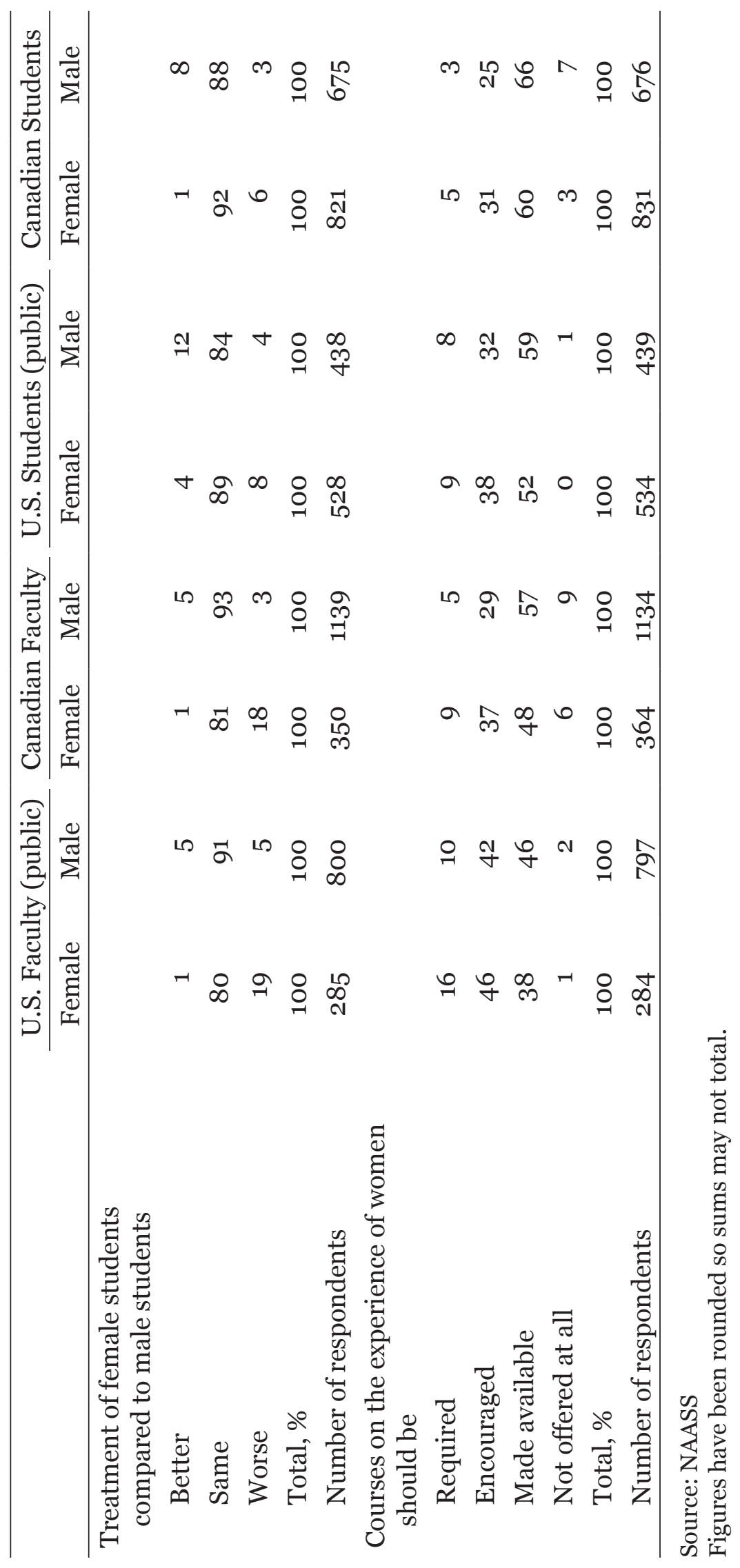




\section{Affirmative Action}

With the exception of White students, Canadian respondents are more opposed than their American counterparts to race or gender-based special preferences, when it comes to either job hiring or university admissions. The national differences are statistically significant at the $0.1 \%$ level, and in both countries, students are more opposed than faculty to such preferences. For example, $75 \%$ of non-White professors in Canada and $54 \%$ of minority professors in public universities in the US are strictly meritocratic in their outlooks; they think that no one should be granted such preferences. This view is held by $89 \%$ of non-White students in Canada and $71 \%$ of students in public colleges and universities in the US. The positional differences concerning special preferences are statistically significant at the $1 \%$ level in all cases. Racial differences on this issue among both Canadian students and U.S. faculty are statistically insignificant. Minority faculty in Canada are more opposed than their U.S. counterparts and, to a lesser extent, White faculty and non-White students in Canada, to admitting more minority students if it means relaxing normal academic requirements (see Table 3).

Staff positional differences between faculty and students are more striking than national differences when it comes to attitudes towards special preferences based on gender or race. In the US, half of female professors, and $86 \%$ of female students, agree with the view that "no one should be given special preference in jobs or college admissions on the basis of their gender or race." This view is held by $57 \%$ of female faculty members and $89 \%$ of female students in Canada. The positional differences on this question among both male and female respondents in the US and Canada are statistically significant at the $0.1 \%$ level.

But gender differences on these issues do matter. Notice that male professors in both countries are more opposed than female professors to either gender- or race-based preferences. The relationship is statistically significant at the $0.1 \%$ level in Canada and the $5 \%$ level in the US. Similarly, male professors and students in both countries are less inclined than their female counterparts to support courses on the experience of women. These differences are also statistically significant.

\section{Multivariate Analysis}

Multivariate analysis of these data provides a sharper picture of both cross-national and positional difference in attitudes of American and Canadian students towards racial issues. It comes as little surprise to discover that race matters to race-related attitudes. African American respondents, both faculty and students alike, are significantly more likely to view America as a racist society. In Canada, being Black is also positively associated with perceptions of racism among students. Notice, however, that race is not a significant predictor of these views among Canadian faculty (see Table 4 and online Appendix C).

Black professors and students in the US and Canada are significantly more likely to report worse treatment of minority students, unfair treatment, and racial discrimination. When other relevant factors are held constant, attitudes of both Black professors and students towards courses concerning racial minorities diverge. Black faculty members and undergraduates in American universities are more inclined than their White counterparts to support the idea of having such courses. The Canadian findings are quite different. For neither faculty nor students does race predict attitudes towards courses concerning the experience of racial minorities in university curriculum (see Appendix C). 
Race, Gender, \& Affirmative Action / I. Katchanovski, N. Nevitte, \& S. Rothman

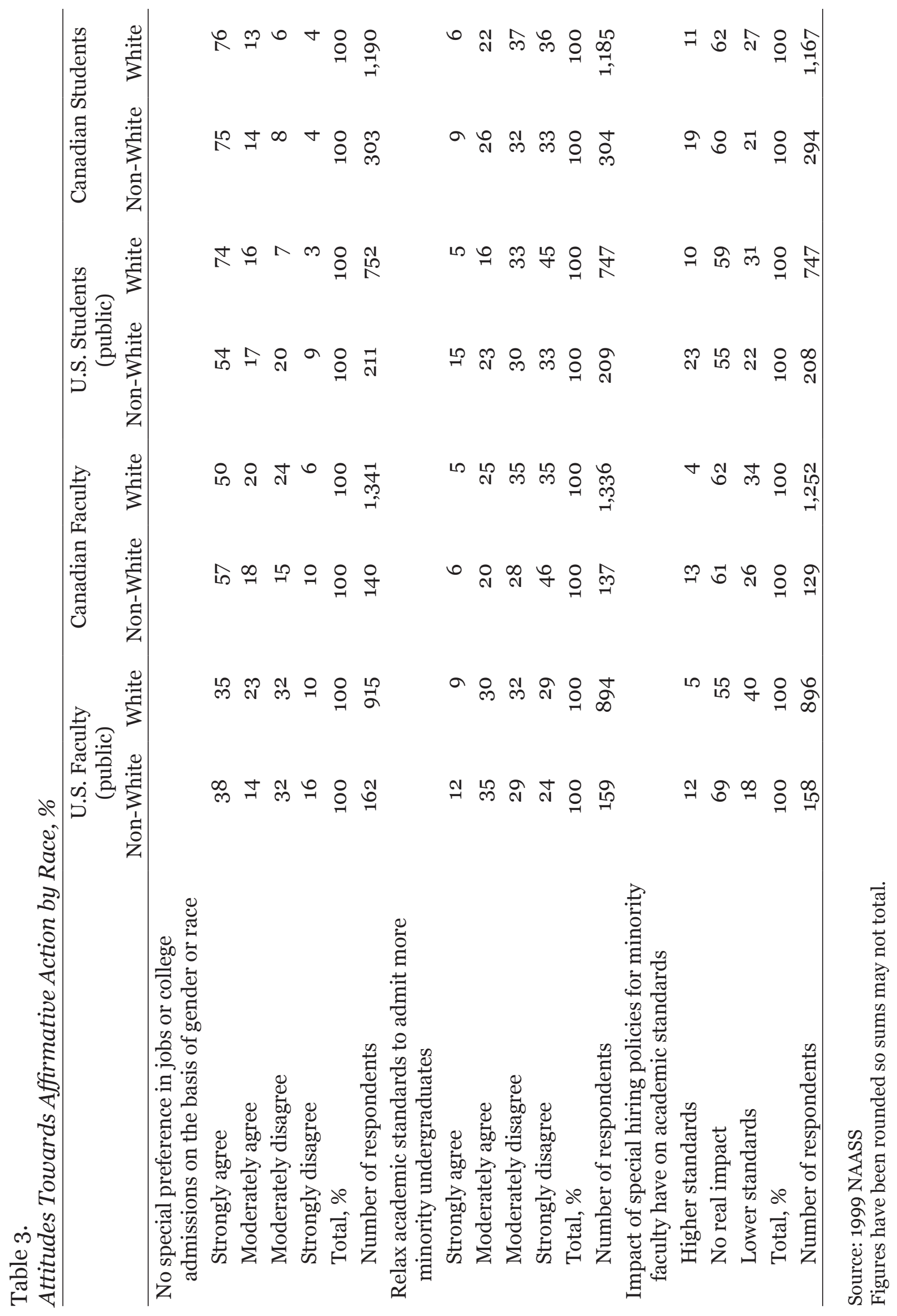


Race, Gender, \& Affirmative Action / I. Katchanovski, N. Nevitte, \& S. Rothman 35

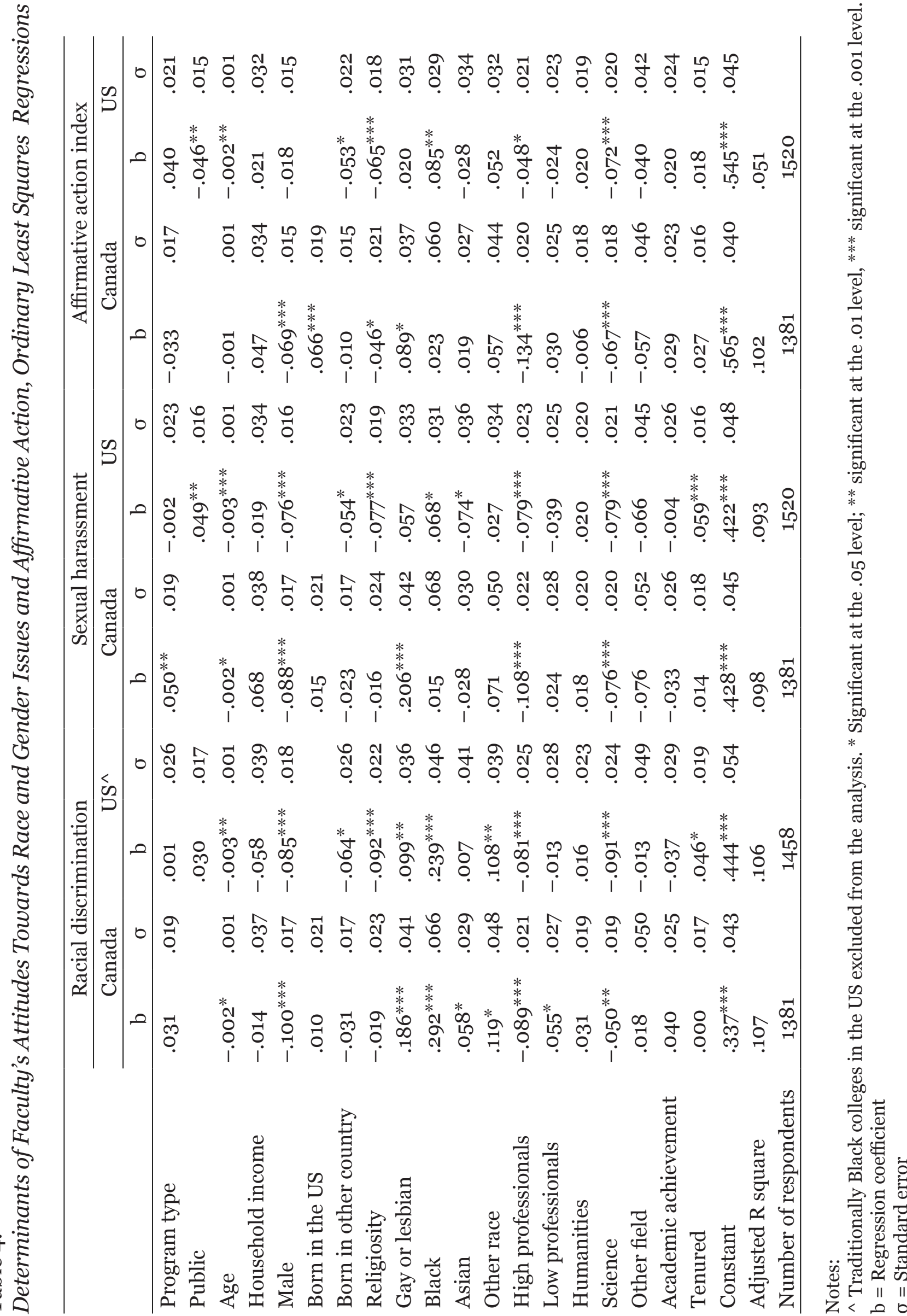


Black faculty and students in the US are significantly more likely than their White counterparts to support affirmative action. In the Canadian case, Black students are different from their White counterparts, but those differences in attitudes towards affirmative action do not extend to faculty. Black faculty and undergraduates in both countries, furthermore, evaluate the effects of special hiring policies on academic standards much more positively than their White counterparts. (Appendix C).

There are also other systematic variations. For example, Asian faculty members in Canada and the US are significantly more likely to report unfair treatment than are their White counterparts. But note that the Asian variable is not a significant predictor of students' perceptions of unfair treatment in either Canada or the US. Those distinctions also shape perceptions about racial discrimination on campus. Asian faculty members (but not students) in Canada are more likely than others to perceive Canada as a racist society. Asian students in the US are more likely to support affirmative action. Asian faculty and students in the US, but not in Canada, are also more likely to perceive the impact of special hiring policies as positive.

It is not surprising to find statistically significant gender differences concerning perceptions of treatment of female students. That finding is true for both faculty and students in Canada and the US. Women, faculty and students alike, are much more inclined than men to think that female students are treated worse than their male counterparts. Similarly, female professors in Canada and the US are more likely than their male counterparts to report unfair treatment and sexual harassment. The greater surprise is that there are no statistically significant gender differences concerning reported unfair treatment and sexual harassment among students in Canada. Unlike their American counterparts, Canadian female students are more supportive than male students of courses on the experience of women (see Table 4 and Appendix C).

There are statistically significant gender differences about affirmative action among faculty and students in both Canada and the US. Female students in both countries are significantly more in favour of affirmative action than male students. Canadian professors, but not American professors, exhibit similar differences on this issue (see Appendix C).

\section{Conclusion}

NAASS provides comparative data concerning attitudes of faculty and students in Canada and the United States towards race, gender, and affirmative action. In this study, the term affirmative action was used in more informal way in the case of Canada, since there are both similarities and differences between affirmative action in the US and employment equity in Canada. Any survey conducted in 1999-2000 may not precisely capture current views of faculty and students toward race, gender, and affirmative action in the US and Canada. But such changes in orientations grounded in core values are likely be relatively gradual.

Systematic analysis of NAASS data points to the conclusion that national factors are more important than positional factors on a number of racial and affirmative action issues in American and Canadian universities. On balance, racial issues tend to be more divisive in the US than in Canada. But the positional differences between students and faculty seem to outweigh American-Canadian differences on a number of gender-related issues. 
In most cases, when other factors are held constant in statistical analysis, the sociodemographic markers of race and gender are significant determinants of attitudes of American and Canadian faculty and students towards racial and gender issues. Given previous research findings, it is not surprising to find that differences between Black and White respondents are pronounced on issues concerning race and affirmative action. Predictably, gender matters to most gender-related issues and to how American and Canadian students and faculty view affirmative action. With some exceptions, female faculty members and students on both sides of the border are significantly more likely than their male counterparts to report sexual harassment on campus, maltreatment of female students, and personal experience of unfair treatment.

These results provide additional support to previous research (Adams, 2004; Lipset, 1990) that emphasizes American-Canadian national differences. Simply put, race and support for affirmative action resonate more powerfully among faculty and students in the US than in Canada. These findings do not imply that Canadian professors and students turn a blind eye to racial discrimination. Rather, the Canadian experience with race and differences in compositions of the population of racial minorities shape rather differently the attitudes of professors and students in the US and Canada towards these issues.

Unlike Black respondents, Asian and White respondents in the U.S. universities are not more divided than their Canadian counterparts concerning racial and affirmative issues. The Asian-White differences are usually statistically insignificant in both countries, particularly among students. Moreover, where statistically significant differences do emerge, they tend to operate in the same direction for students and professors alike. There are also cross-national variations; some findings are statistically significant in Canada but not in the US. As the data show, the sole exception emerges in the case of the affirmative-action index among students.

The multivariate analysis of the data clearly indicates that history matters. Value differences linked to different historical experiences of Blacks and Whites in the US and Canada manifest themselves in both national and Black-White disparities concerning attitudes towards race and affirmation action. The Black-White differences are much more pronounced in the US than in Canada. There are statistically significant Asian-White differences among students in the US but not in Canada.

However, positional differences between American and Canadian professors and students also matter. And they matter most when it comes to issues related to gender. The uneven findings concerning Asian students and faculty, and the clarity of the Black-White differences are intriguing. One implication might be that the historical legacy woven around Asian versus White dimensions is less divisive than Black-White differences.

\section{Notes}

1. The US sample was stratified by institution type according to the Carnegie classifications of doctoral, comprehensive, and liberal arts schools. Within each strata, these schools were randomly selected from the entire universe of qualified institutions; the probability of selection was proportional to the size of each institution (faculty and student body combined). In the Canadian case, the universe of universities is smaller, prompting a different sampling approach. But the logic of stratification and sampling is comparable. The Canadian sample was also stratified by type of institution. It in- 
cluded all 15 schools from the doctoral strata, 12 out of 13 comprehensive schools, and 8 out of 24 liberal arts schools. Within the strata, the Canadian sample data were collected from each institution in proportion to each institution's population.

2. There are also colleges affiliated with religious institutions in Canada. Canadian religious institutions were not included in the 1999 NAASS. They have a very small percentage of the total Canadian population of faculty and students. Public schools represent $72 \%$ of the US faculty sample and $71 \%$ of the student sample.

3. See Appendix A for wording and coding of the questions. This and other appendices are available on the website of the main author: https://www.academia.edu/17178966/ Online_Appendix_A_B_and_C_Race_Gender_and_Affirmative_Action_Attitudes_in_American_and_Canadian_Universities.

4. A public institution dummy variable in regressions dealing with the U.S. sample controls for the effect of this factor in the multivariate analysis.

5. Although the national samples of NAASS are large, the numbers of the respondents in some racial groups are small. For this reason, we did not create separate categories for native Indian, Aboriginal, and Hispanic respondents.

6. The dependent and independent are recoded and standardized with a range from o to 1.

7. The academic achievement index is derived from a factor analysis of NAASS questions concerning the number of articles and book chapters published in the last five years, the number of books authored or co-authored in the last five years, percent of working time spent on research, service on editorial board of a journal, and attendance at international meetings. (Appendix B). The results of the factor analysis produce a single-factor solution with a reliability coefficient of the index (alpha) of 0.69.

8. Other socio-economic, institutional, and academic variables were included in the analysis, but, with few exceptions, they had no statistically significant effects.

9. Professionals are divided into two categories: low professionals and high professionals. Professors and students from such disciplines such as business, architecture, engineering, and communication comprise a category of "high professionals." The "low professionals" field includes faculty in disciplines such as nursing, education, and social work. Studies show that these groups in the US and Canada differ in terms of their academic and political views (Ladd \& Lipset, 1975; Lipset et al., 2004; Nakhaie \& Brym, 1999).

\section{References}

Adams, M.(2004). Fire andice: The United States, Canada and the myth of converging values. Toronto, ON: Penguin Canada.

Abramson, P. R., \& Inglehart, R. (1995). Value change in global perspective. Ann Arbor, MI: University of Michigan Press.

Agocs, C. (ed.). (2002). Workplace equality. Hague, Netherlands: Kluwer.

Alston, J. P., Morris, T. M., \& Vedlitz, A. (1996). Comparing Canadian and American values: New evidence from national surveys. The American Review of Canadian Studies/ The Canadian Review of American Studies, 26(Autumn), 301-314.

Anderson, T. H. (2004). The pursuit of fairness: A history of affirmative action. New York, NY: Oxford University Press. 
Ancis, J. R., Sedlacek, W. E., \& Mohr, J. J. (2000). Student perceptions of campus cultural climate by race. Journal of Counseling \& Development, 78(Spring), 180-85.

Astin, A., Korn, W., \& Dey, E. (1991). The American college teacher: National norms for the 1989-90 HERI Faculty Survey. Los Angeles, CA: Higher Education Research Institute.

Bain, O., \& Cummings, W. (2000). Academe's glass ceiling: societal, professionalorganizational, and institutional barriers to the career advancement of academic women. Comparative Education Review, 44(4), 493-514.

Bercuson, D., Bothwell, R., \& Granatstein, J. L. (1997). Petrified campus: The crisis in Canada's universities. Toronto, ON: Random House Canada.

Bonilla-Silva, E. (2006). Racism without racists: Color-blind racism and the persistence of racial inequality in the United States. Lanham, MD: Rowman \& Littlefield.

Boyer, E. L. (1990). Scholarship reconsidered: priorities of the professoriate. Princeton, NJ: Carnegie Foundation for the Advancement of Teaching.

Brooks, R. L. (2005). Affirmative action in higher education: What Canada can take from the American experience. Windsor Yearbook of Access to Justice, 23, 193-226.

CAUT almanac of post-secondary education 2006. (2006). Ottawa, ON: Canadian Association of University Teachers.

Canadian University Survey Consortium.(2008).Undergraduate student survey $\square$ June 2008. Canadian University Survey Consortium. Winnipeg MB: PRA Inc. Retrieved from http://www.cusc-ccreu.ca/publications/2008_cusc_masterreport.pdf

Chan, A. S. (2005). Policy discourses and changing practice: diversity and the university-college. Higher Education, 5O(1), 129-57.

Egan,T.(2007).LittleAsia on theHill.NewYorkTimes,January7.Retrievedfromhttp:// www.nytimes.com/2007/01/o7/education/edlife/o7asian.html?pagewanted=all\&_r=0

Feagin, J. R., Vera, H., \& Imani, N. (1996). The Agony of education: Black students at White colleges and universities. New York, NY: Routledge.

Gmelch, S. (1998). Gender on campus: Issues for college women. New Brunswick, NJ: Rutgers University Press.

Goyder, J. (1992). Gender inequalities in academic rank. Canadian Journal of Sociology, 17(3), 333-43.

Grayson, J. P. (1995). Does race matter? Outcomes of the first year experience in a Canadian university. Canadian Journal of Higher Education, 25(2), 79-109.

Henry, F., \& Tator, C. (1994). Racism and the university. Canadian Ethnic Studies, 26(3), 74-90.

Inglehart, R., Nevitte, N., \& Basanez, M. (1996). The North American trajectory: Cultural, economic, and political ties among the United States, Canada, and Mexico. New York, NY: Aldine De Gruyter.

Joshee, R., \& L. Johnson (Eds.). (2007) Multicultural education policies in Canada and the United States. Vancouver, BC: UBC Press. 
Katchanovski, I., Rothman, S., \& Nevitte, N. (2011). Attitudes towards faculty unions and collective bargaining in American and Canadian universities. Relations industrielles/ Industrial Relations, 66(3), 349-373.

Kinder, D. R., \& Sanders, L. M.(2006). Divided by color: Racial politics and democratic ideals. Chicago, IL: University of Chicago Press.

Ladd, E. C., \& Lipset, S. M. (1975). The Divided academy: Professors and politics. New York, NY: McGraw-Hill.

Levine, A., \& Cureton, J. S. (1998). When Hope and fear collide: A portrait of today's college student. San Francisco, CA: Jossey-Bass Publishers.

Lipset, S. M. (1990). Continental divide: the values and institutions of the United States and Canada. New York, NY: Routledge.

Lipset, S. M., Meltz, N., Gomez, R., \& Katchanovski, I. (2004). The Paradox of American and Canadian unionism: Why Americans like unions more than Canadians do, but join much less. Ithaca, NY: Cornell University Press.

Nakhaie, M. R. (2002). Gender differences in publication among university professors in Canada. Canadian Review of Sociology and Anthropology, 39(2), 151-79.

Nakhaie, M. R. (2004). Who controls Canadian universities? Ethnoracial origins of Canadian university administrators and faculty's perception of mistreatment. Canadian Ethnic Studies, (1), 92-110.

Nakhaie M. R., \& Brym, R. J. (1999). The political attitudes of Canadian professors. Canadian Journal of Sociology, 24(3), 329-53.

Nevitte, N. (1996). The decline of deference: Canadian value change in cross national perspective. Peterborough, ON: Broadview Press.

NAASS (1999). North American Academic Study Survey. Seymour Martin Lipset, Neil Nevitte, and Stanley Rothman (Principal investigators).

OECD. (2011). Education at a glance 2011: OECD Indicators. Retrieved from http:// www.oecd.org/edu/eag2011

Rothman, S., Lichter, R., \& Nevitte, N. (2005). Politics and professional advancement among college faculty. Forum, 3(1).

Rothman, S., Lipset, S. M., \& Nevitte, N. (2003). Does enrollment diversity improve university education? International Journal of Public Opinion Research, 15(1), 8-26.

Samuel, E., \& Burney, S. (2003). Racism, eh? Interactions of South Asian students with mainstream faculty in a predominantly White Canadian university. Canadian Journal of Higher Education, 33(2), 81-114.

Saunders, M., Therrien, M., \& Williams, L. (1992). Women in universities: Survey of the status offemale faculty and students at Canadian universities. Ottawa, ON: Canadian Federation of University Women.

Snyder, T.D., Tan, A.G., \& Hoffman, C.M. (2006). Digest of Education Statistics 2005. U.S. Department of Education, National Center for Education Statistics. Washington, DC: U.S. Government Printing Office. (Publication No. NCES 2006-030). Retrieved from http://nces.ed.gov/pubs2006/2006030_1.pdf. 
Taylor, E., Gillborn, D., \& Ladson-Billings, G. (Eds.). (2009). Foundations of critical race theory in education. New York, NY: Routledge.

Toutkoushian, R., \& Conley, V. (2005). Progress for women in academe, yet inequities persist: Evidence from NSOPF:99. Research in Higher Education, 46(1): 1-27.

U.S. Department of Education. National Center for Education Statistics. (2004). National study of postsecondary faculty. Report on Faculty and Instructional Staff in Fall 2003., (Publication No. NSOPF:04). (ED485364).

White, J. K. (2003). Values divide: American politics and culture in transition. New York, NY: Chatham House.

\section{Contact Information}

Ivan Katchanovski

School of Political Studies

University of Ottawa

ikatchan@uottawa.ca

Ivan Katchanovski is part-time professor in the School of Political Studies at the University of Ottawa. His academic publications include three books and 15 refereed articles.

Neil Nevitte is a professor in the Department of Political Science and in the School of Public Policy and Governance at the University of Toronto. His research interests are in the areas of public opinion, elections, and value change.

Professor Stanley Rothman was director of the Center for the Study of Social and Political Change and professor in the Department of Government at Smith College. He passed away before this study was completed. 